\title{
Preliminary assessement of the estrogenic potential of Apuleia leiocarpa (Vogel) J.F. Macbr., Fabaceae, Platypodium elegans Vogel, Fabaceae, and Brosimum guianense (Aubl.) Huber, Moraceae, on the wistar rat reproductive system
}

\author{
Rita de Cássia da Silveira e Sá, ,' Vera Maria Peters, ${ }^{2}$ Martha de Oliveira Guerra ${ }^{2}$
}

\author{
${ }^{1}$ Departamento de Fisiologia e Patologia, Universidade Federal da Paraíba, Campus Universitário, 58059-900 \\ João Pessoa, PB, Brazil, \\ ${ }^{2}$ Centro de Biologia da Reprodução, Universidade Federal de Juiz de Fora, Juiz de Fora, Campus Universitário, \\ 36036-330 Juiz de Fora-MG, Brazil
}

\begin{abstract}
RESUMO: Avaliação preliminar do potencial estrogênico de Apuleia leiocarpa (Vogel) J.F. Macbr., Fabaceae, Platypodium elegans Vogel, Fabaceae, and Brosimum guianense (Aubl.) Huber, Moraceae, no sistema reprodutor de ratos Wistar". Um grupo de primatas da espécie Alouatta guariba foi estudado em seu habitat natural na Mata Atlântica, onde foi observada uma drástica redução populacional dessa espécie. Suspeita-se que essa redução se deve à inibição da fertilidade das fêmeas devido ao consumo de Apuleia leiocarpa (Vogel) J.F. Macbr., Fabaceae, Platypodium elegans Vogel, Fabaceae e Brosimum guianense (Aubl.) Huber, Moraceae. Estudos fitoquímicos indicaram a presença de cumarinas, especialmente em B. guianense e P. elegans, cujo efeito adverso no desenvolvimento de folículos ovarianos foi previamente relatado em ratas. Este trabalho investiga a atividade estrogênica dessas plantas no útero e vagina utilizando ratas castradas como modelo experimental. Ratas Wistar pubescentes castradas foram tratadas por cinco dias com os extratos hidroalcoólicos de A. leiocarpa, P. elegans and B. guianense $(50 \mathrm{mg} /$ rata). Foram analisados os seguintes parâmetros: peso de útero e hipófise, cornificação e abertura vaginal. Os resultados preliminares obtidos mostraram que a administração dos extratos não alterou significativamente as variáveis analisadas, indicando, indiretamente, a ausência de efeito estrogênico no sistema reprodutor das ratas tratadas com as plantas citadas. Esses dados sugerem que o consumo dessas plantas não está relacionado com a redução populacional observada no grupo de primatas da espécie $A$. guariba.
\end{abstract}

Unitermos: Alouatta guariba, Apuleia leiocarpa, Brosimum guianense, atividade estrogênica, Platypodium elegan, rato Wistar.

\begin{abstract}
A group of primates (Alouatta guariba) was studied in its natural habitat, where a drastic population reduction was detected. It is suspected that this reduction is due to the inhibition of fertility caused by the consumption of Apuleia leiocarpa (Vogel) J.F. Macbr., Fabaceae, Platypodium elegans Vogel, Fabaceae, and Brosimum guianense (Aubl.) Huber, Moraceae. These plants are reported to have cumarins, which have been shown to affect ovarian follicular development in rats. This work investigates the estrogenic activity of these plants on the uterus and vagina using castrated rats as the biological model. Pubescent castrated rats were treated for five days with $A$. leiocarpa, P. elegans and B. guianense hydroalcoholic extracts $(50 \mathrm{mg} / \mathrm{rat})$. Uterus and pituitary gland weight, vaginal cornification and opening were evaluated. The results showed that the administration of the extracts did not significantly alter the parameters analyzed. This preliminary investigation indirectly indicates the absence of estrogenic effect on the rat reproductive system and no relation to the population reduction of this particular group of primates.
\end{abstract}

Keywords: Alouatta guariba, Apuleia leiocarpa, Brosimum guianense, estrogenic activity; Platypodium elegan, Wistar rat. 


\section{INTRODUCTION}

A group of primates from the species Alouatta guariba (Alouatta fusca Geoffrey, 1812, previously), popularly known as brown-howler monkey and classified as near threatened on the International Union for the Conservation of Nature and Natural Resources (IUCN) red list 2007, was studied in its natural habitat in the Atlantic Forest located at Mata da Boa Vista in the district of Comendador Levy Gasparian, Rio de Janeiro State (Brazil), where a drastic populational reduction of this species was detected (Limeira, 1996). A populational density survey showed that the number of animals found at Mata da Boa Vista was much lower than that of other groups of the same primate species from other areas in Brazil, namely Reserva da Cantereira and Lageadinho (São Paulo State), and Estação Biológica de Caratinga (Minas Gerais State) (Limeira, 1996).

The differences observed in the population density of primates can be due to several factors, including habitat destruction, food availability, hunting, diseases and aggressive social behavior. One additional factor that is seldom questioned and might explain this reduction is the inhibition of fertility caused by the consumption of certain types of plants found in the Atlantic Forest which could be interfering with the reproductive cycle of primates. For instance, in many plants it is common the occurrence of substances, such as flavonoids and phytosterols (sitosterol and stigmasterol), which have similar activity to that of the natural hormones (Salah et al., 2002). A quantitative study of the $\operatorname{diet}$ of A. guariba at Mata da Boa Vista indicated that the most frequently consumed plant species were Apuleia leiocarpa (Vogel) J.F. Macbr., Fabaceae (Correa, 1984b), Platypodium elegans Vogel, Fabaceae (Silva Jr, 1981; Correa, 1984a), and Brosimum guianense (Aubl.) Huber, Moraceae (Correa, 1984b; Limeira, 1996). Phytochemical studies have shown the presence of sitosterol and stigmasterol in $P$. elegans and cumarins in $B$. guianense and P. elegans (Amaral et al., 2001; Amaral, 1997) which have been reported to affect ovarian follicular development in rats (Ulubelen et al., 1994). The relationship between the chemical composition of plants and feeding strategies of primates has been investigated by many authors (Glander, 1979; Milton, 1979; Rodriguez et al., 1985; Barton et al., 1993). In 1995, Stryer observed that female primates of the species Brachyteles arachnoides (muriqui) showed a specific feeding habit by increasing the consumption of $A$. leiocarpa and P. elegans only during mating season.

The investigation of how plant constituents may act or affect the organism has already been addressed in various animal species. In rodents, many studies have reported the estrogenic and anti-estrogenic effects of plant extracts on the female reproductive system, giving emphasis to their action on the uterus and vagina through the occurrence of histological alterations and cornification of the vaginal epithelium (Shukla et al., 1989; Tewari et al., 1989; Johri et al., 1991), their interference in the implantation (Montanari \& Bevilacqua, 2002; Salah et al., 2002), and their abortifacient activity (Lutterodt, 1988; Badami et al., 2003).

Considering the issue of species preservation and the ecological implications that may result from its disappearance, it is important to identify the food sources that have compounds among their constituents capable of interfering with fertility, which could be responsible for the reduction of primates' populations. Such compounds may have an effect similar to that of hormones, such as estrogen, that are known to affect fertility. Therefore, the purpose of this work was to investigate the estrogenic activity of A. leiocarpa, P. elegans and B. guianense using rats as the biological model.

\section{MATERIALS AND METHODS}

\section{Plant material}

Apuleia leiocarpa (Vogel) J.F. Macbr., Fabaceae, Platypodium elegans Vogel, Fabaceae, and Brosimum guianense (Aubl.) Huber, Moraceae were collected in Mata da Boa Vista, district of Comendador Levy Gasparian, Rio de Janeiro State, Brazil. The species were authenticated by H. B. Lima from Instituto Jardim Botânico (Rio de Janeiro) and voucher specimens were deposited at the Herbarium of Museu Nacional-UFRJ, Rio de Janeiro (Amaral et al., 1997; Amaral, 2001). The hydroalcoholic extracts were prepared by Dr. Gilda Guimarães Leitão and Dr. Suzana Guimarães Leitão from the Biology Laboratory, Natural Products Research Center (Federal University of Rio de Janeiro-UFRJ) using aerial parts of these plants.

\section{Animals and housing}

Pubescent female Wistar rats (Rattus norvegicus Berkenhout, 1769), weighing around $40 \mathrm{~g}$, were obtained from the vivarium of UFJF, where they were born and bred. They were housed individually under standard laboratory conditions with a $12 \mathrm{~h}$ light/ $12 \mathrm{~h}$ dark photoperiod. They were fed on rat chow pellets and received water ad libitum. Animal care and the experimental protocol followed the principles and guidelines suggested by the Brazilian College of Animal Experimentation (COBEA) and were approved by the Ethical Committee of the Federal University of Juiz de Fora (protocol number 019/2004 - CEA - UFJF).

\section{Bioassay}

The biological assay used to study the estrogenic effect follows the guidelines proposed by the Organization for Economic Cooperation and Development (OECD Reprotox Protocol) with modifications. In brief, this protocol comprises the analysis of vaginal cornification, vaginal opening, pituitary gland and uterus weight gain. 
The presence of cornified cells in the vagina and the presence of mitosis in the uterin glands and endometrium were used as indicatives of occurrence of estrogenic effect (OECD, 2007).

The rats were randomly divided into eight groups of ten animals each and underwent bilateral ovariectomy at 28 days of age. Briefly, the animals were anesthetized with $10 \mathrm{mg} / \mathrm{kg}$ xylazine and $90 \mathrm{mg} / \mathrm{kg}$ ketamine i.p. and following hair removal at the site of the operation, an antiseptic wash with an organic iodine preparation was applied on the surface of the skin to prevent infection. The anaesthetized animal was laid on its ventral surface and a small midline dorsal skin incision was made approximately half way between the middle of the back and the base of the tail. Entrance to the peritoneal cavity was gained through muscle incisions made half to two-thirds of the way down the side of the body, where the ovary was removed after being separated from its surrounding fat deposits (Waynforth \& Flecknell, 1994)). After surgery, the animals were given 15 days to recover prior to drug administration. They were then treated for five days (Gray et al., 2004) as follows:

Group 1: hydroalcoholic extract of A. leiocarpa $(50 \mathrm{mg}$ / $\mathrm{kg})-v . o$.

Group 2: hydroalcoholic extract of $P$. elegans $(50 \mathrm{mg} / \mathrm{kg})$ $-v . o$

Group 3: hydroalcoholic extract of B. guianense $(50 \mathrm{mg}$ / $\mathrm{kg})-$ v.o.

Group 4: estrogen dissolved in corn oil $(50 \mu \mathrm{g} / \mathrm{kg})$ - i.p.

Group 5: corn oil $(0.1 \mathrm{~mL} / \mathrm{kg})$ - i.p.

Group 6: hydroalcoholic solution 50\% $(0.5 \mathrm{~mL} / \mathrm{kg})-v . o$.

Group 7: Ovariectomy - no treatment

Group 8: colony control - no treatment.

The hydroalcoholic extracts were administered at a dose level which corresponded to $1 \%$ of the highest dose used on reproductive toxicological assays $(5 \mathrm{~g} /$ kg) (Chan \& Hayes, 1994). During the experiment, the animals were inspected daily for detection of clinical signs of toxicity, such as piloerection, and alterations in locomotor activity (Christian, 2001). Body weight was recorded before the beginning of treatment, and at the end of treatment. The animals were killed by an overdose inhalation of anesthetic (halothane) $24 \mathrm{~h}$ after the last treatment. Before death, the genital region was inspected for observation of the vaginal opening and, immediately after death, the animals underwent laparotomy for removal of the uterus, vagina and pituitary gland. The uterus and pituitary gland were weighed. After that, the uterus and vagina were fixed in Bouin for histological examination. The tissues were dehydrated in a graded series of ethanol, embedded in paraffin and sectioned at $7 \mu \mathrm{m}$ thickness for routine haematoxylin and cromotrope staining, and light microscope examination (Michalany, 1998).

\section{Statistical analysis}

The data were analyzed using the One-way analysis of variance (ANOVA) followed by Tukey's multiple comparison test $(\alpha=0.05)$. The presence or absence of mitosis and vaginal opening were analyzed using the $\mathrm{X}^{2}$ test $(\alpha=0.05)$ (Sokal \& Rohlf, 1996).

\section{RESULTS}

During the experimental procedure no deaths and no clinical signs of toxicity such as locomotor activity alterations and piloerection were detected in any of the groups. Table 1 shows that at the end of the five-day treatment period body weight gain was not significantly different when comparing the extract, vehicle, ovariectomized and estrogen-treated groups with the colony control group. The weight of the uterus was significantly increased in the estrogen-treated group and, as expected, castration reduced the weight of the uterus of all other groups; however, the extract did not induce any uterotrophic effects (Table 2). The weight of the pituitary gland of the vehicles, extract and estrogen-treated groups was not significantly altered when compared to the colony control. In particular, P. elegans-treated rats showed a reduction in the pituitary gland weight, but the mean value obtained did not differ statistically from that of the ovariectomized group (Table 2).

Table 1. Body weight of Wistar rats treated with Apuleia leiocarpa, Brosimum guianense and Platypodium elegans extract, corn oil, estrogen, alcohol 50\%, ovariectomized and colony control.

\begin{tabular}{lcc}
\hline \multirow{2}{*}{ Groups } & \multicolumn{2}{c}{ Weight $(\mathrm{g})$} \\
\cline { 2 - 3 } & \multicolumn{1}{c}{ Body 1 } & Body 2 \\
\hline A. leiocarpa & $44.62 \pm 1.25$ & $75.74 \pm 2.58$ \\
B. guianense & $41.61 \pm 6.73$ & $77.14 \pm 7.28$ \\
P. elegans & $39.61 \pm 3.05$ & $67.40 \pm 7.56$ \\
Alcohol 50\% & $42.27 \pm 1.65$ & $74.71 \pm 3.65$ \\
Corn oil & $37.16 \pm 1.60$ & $69.73 \pm 4.03$ \\
Ovariectomy & $48.79 \pm 4.26$ & $79.11 \pm 6.11$ \\
Estrogen & $36.43 \pm 2.05$ & $63.59 \pm 4.07$ \\
Colony control & $38.09 \pm 3.56$ & $67.88 \pm 9.03$ \\
\hline
\end{tabular}

The results were expressed by mean \pm standard deviation (SD). $p>0.05$. Body 1 and 2 - body weight before the beginning and at the end of treatment, respectively. $\mathrm{n}=0$.

Premature opening of the rat's vaginal membrane follows the administration of estrogen. In this experiment, at the time of death ( 48 days old), the vaginal opening was observed in all estrogen-treated animals whereas in the extract-treated and vehicle groups only $50 \%$ and $30 \%$, of the animals, respectively, exhibited this trait.

The uterus and vagina sections showed that the administration of the hydroalcoholic extract of A. leiocarpa, 
P. elegans and B. guianense, during five days, did not cause any visible morphologic alteration of the uterine and vaginal walls of castrated rats. The administration of these plant extracts did not induce cellular proliferation, which is represented by the occurrence of mitotic figures in the epithelium of the uterus and the endometrial glands. The uterus wall showed a simple columnar epithelium lining its mucosa, the adjacent muscle layers (the myometrium) and the perimetrium with no morphological alteration due to treatment (Figures 1a, b and c). The vagina presented a normal stratified squamous epithelium without any signs of cornification typical of the estrogen effect.

In the estrogen-treated control rats, the uterine wall showed increased activity of cell division and mitotic figures. Epithelium proliferation was observed in the endometrial glands (Figure 1f) as well as in the uterine lining which showed a pseudostratified epithelium. The exposure to estrogen enhanced mitosis in the vaginal epithelium showing areas of pseudostratified epithelium and also areas of keratinized stratified squamous epithelium. The other control groups did not show any morphologic alterations in the uterus (Figures 1d and e) or vagina.

Table 2. Uterus and pituitary gland weights of Wistar rats treated with Apuleia leiocarpa, Brosimum guianense and Platypodium elegans extract, corn oil, estrogen, alcohol 50\%, ovariectomized and colony control.

\begin{tabular}{lcc}
\hline \multirow{2}{*}{ Groups } & \multicolumn{2}{c}{ Weight $(\mathrm{mg})$} \\
\cline { 2 - 3 } & Pituitary gland & Uterus \\
\hline A. leiocarpa & $3.50 \pm 0.38$ & $18.06 \pm 4.25$ \\
B. guianense & $3.64 \pm 0.94$ & $14.32 \pm 2.32$ \\
P. elegans & $2.98 \pm 0.40$ & $16.52 \pm 5.03$ \\
Alcohol 50\% & $3.48 \pm 0.28$ & $15.27 \pm 2.53$ \\
Corn oil & $3.98 \pm 0.40$ & $29.48 \pm 9.84$ \\
Ovariectomy & $3.87 \pm 0.73$ & $15.53 \pm 2.28$ \\
Estrogen & $3.77 \pm 0.76$ & $101.30 \pm 12.81^{*}$ \\
Colony control & $3.19 \pm 0.90$ & $45.24 \pm 18.00$ \\
The results were expressed by mean \pm standard deviation (SD). $p<0.001$. \\
$\mathrm{n}=10$.
\end{tabular}

\section{DISCUSSION}

The mammal feminine genital tract and the ovary are under the control of hormones capable of causing histological and physiological alterations that directly influence sexual maturation and the reproductive behavior of the species (Eckert et al., 1988). When a hormonal imbalance occurs, these hormones can interfere in the natural process of animal reproduction, inhibiting the proliferation of the species, which may lead to disastrous consequences to the environment (Tewari et al., 1989). The most important hormones involved in the regulation of the alterations detected in the feminine genital tract are estrogen and progesterone, which are regulated by pituitary-secreted gonadotropin hormones (Brann et al., 1995).
The hypertrophic response of the rodent uterus is one of the widely used tests in monitoring the estrogenic/ antiestrogenic potency of various drugs and chemicals (Khan-Dawood \& Satyaswaroop, 1995). Previous works have reported the endogenous and exogenous estrogenic and antiestrogenic activity of different compounds in this group of animals (Brann et al., 1995); many of them have shown that ovariectomy results in depletion of endogenous estrogens, and the exposure to exogenous estrogens or phytoestrogens can enhance mitosis and therefore provoke epithelium proliferation of the genital tract (Ravichandran et al., 2007). Another group of phytochemicals found in the plants employed in this study, namely sitosterol and stigmasterol are phytosterols that are chemically similar to animal cholesterol. Sitosterol is mainly known and used for its cholesterol lowering property and stigmasterol is used as a precursor in the manufacture of synthetic progesterone, that plays an important physiological role in the regulatory and tissue rebuilding mechanisms related to estrogen effects, as well as acting as an intermediate in the biosynthesis of androgens, estrogens, and corticoids (Peterson, 1995). Moreover, cumarin, a natural product also found in the plants of this study, has also been reported to have antifertility activity in mature female rats (Ulubelen etal., 1994).

In the present work, ovariectomized Wistar rats treated with A. leiocarpa, P. elegans and B. guianense hydroalcoholic extracts did not show any histological alterations on the uterine and vaginal wall. The most common estrogenic effects, such as cell proliferation in the endometrium, immature vaginal opening and cornification, which were observed in the estrogen-treated rats of this experiment, were absent from the groups treated with the plant extracts. The weight of the pituitary gland and uterus was not significantly altered in the groups treated with the extracts and neither was any early vaginal opening detected in those groups. These facts indirectly indicate the absence of functional alterations caused by estrogenic influence.

In conclusion, considering the bioassay used in this work, A. leiocarpa, P. elegans and B. guianense extracts did not seem to have estrogenic effect on the Wistar rat reproductive system, given that the histoarchitecture of the uterus and vagina of these animals was kept intact. These data suggest that the ingestion of $A$. leiocarpa, $P$. elegans and $B$. guianense could not be held accountable for the populational reduction of the howler monkeys in the Brazilian Atlantic forest.

\section{ACKNOWLEDGEMENTS}

The authors are grateful to Paulo Sérgio do Carmo for the technical assistance and Dr. Dr. Gilda Guimarães Leitão and Dr. Suzana Guimarães Leitão for supplying the plant extracts and Ms Angela Harman for reviewing the English version of the manuscript. 

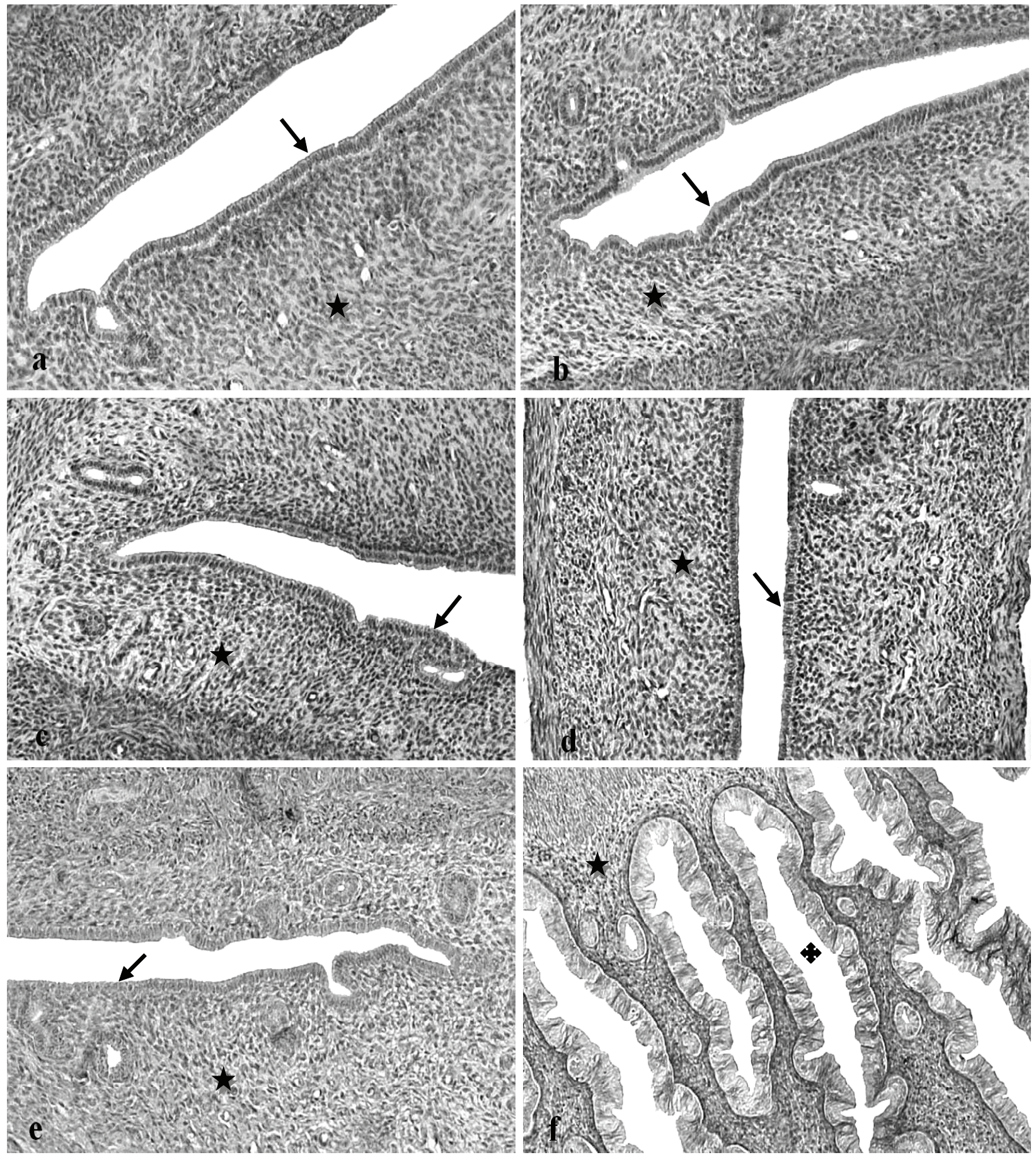

Figure 1. Transverse section of the uterus of ovariectomized rats treated with (a) A. leiocarpa, (b) P. elegans and (c) B. guianense hydroalcoholic extract, (d) hydroalcoholic solution $50 \%$ and (e) untreated showing no morphologic alteration of the uterine wall. (f) estrogen-treated ovariectomized rats showing the uterine wall with increased epithelium of the endometrial gland (crossed arrows). Arrow - simple columnar epithelium; black star - stroma of the endometrium. (100x). 


\section{REFERENCES}

Amaral LFG 1997. Estudo químico-ecológico das plantas da dieta de um grupo de barbados: Alouatta fusca (primates Cebidae). Doutorado. Universidade Federal do Rio de Janeiro, Programa de Química de Produtos Naturais, $180 \mathrm{p}$.

Amaral LFG, Leitão SG, Monache, FD, Leitão GG 2001. 3,4Seco-lupanes and other constituents from Platypodium elegans. Fitoterapia 72: 441-443.

Badami S, Aneesh R, Sankar S, Sathishkumar MN, Suresh B, Rafan S 2003. Antifertility activity of Derris brevipes variety coriacea. J Ethnopharmacol 84: 99-104.

Barton RA, Whiten A, Byrne RW, English M 1993. Chemical composition of baboon plant foods: implication for the interpretation of intra- and interspecific differences in diet. Folia Primatol 61: 1-20.

Brann DW, Mills TM, Mahesh VB 1995. Female reproduction: The ovulatory cycle. In: Witorsch RJ (Ed.) Reproductive Toxicology. 2 ed. New York: Raven press, p. 23-44.

Chan PKP, Hayes AW 1994. Acute toxicity and eye irritancy. In: Hayes AW (Ed.) Principles and methods of toxicology. 3 ed.New York: Raven Press, p. 579-647.

Christian MS 2001. Test methods for assessing female reproductive and developmental toxicology. In: Hayes W. (Ed.) Principles and Methods of Toxicology. 4 ed. Philadelphia: Taylor \& Francis, p. 1301-1381.

Correa MP 1984a. Dicionário das plantas úteis do Brasil e das exóticas cultivadas. Ministério da Agricultura: Instituto Brasileiro de Desenvolvimento Florestal 3: 39-40.

Correa MP 1984b. Dicionário das plantas úteis do Brasil e das exóticas cultivadas. Ministério da Agricultura: Instituto Brasileiro de Desenvolvimento Florestal 5: 251-254.

Eckert R, Randall D, Augustine G 1988. Animal physiology: mechanisms and adaptations. 3 ed. New York: WH Freeman and Company, p. 266-328.

Glander KE 1979. Howling monkey feeding behavior and plant secondary compounds: a study on strategies. In: Montgomery GG (Ed.) The ecology of arboreal folivores. Washington, D.C.: Smithsonian Institution Press, p. 561574.

Gray Jr LE, Wilson V, Noriega N, Lambright C, Furr J, Stoker TE, Laws SC, Goldman J, Cooper RL, Foster PMD 2004. Use of the laboratory rat as a model in endocrine disruptor screening and testing. ILAR Journal 45: 425-437,.

Johri RK, Pahwa GS, Sharma SC, Zutshi U 1991. Determination of estrogenic/antiestrogenic potential of antifertility substances using rat uterine peroxidase assay. Contraception 44: 549-557.

Khan-Dawood FS, Satyaswaroop PG 1995. Toxic effects of chemicals and drugs on the sex accessory organs in the nonpregnant female. In: Witorsch RJ (Ed.) Reproductive Toxicology. 2 ed. New York: Raven press, p. 159-173.

Limeira VLAG 1996. Comportamento alimentar, padrão de atividades e uso do espaço por Alouatta fusca (primates, Platyrrhini) em um fragmento degradado de floresta atlântica do Estado do Rio de Janeiro. Dissertação de Mestrado. Universidade Federal do Rio de Janeiro, Ciências Biológicas (Zoologia), 135p.

Lutterodt GD 1988. Abortifacient properties of an extract from Fida veronicaefolia. J Ethnopharmacol 23: 27-33.

Michalany J 1998. Técnica histológica em anatomia patológica.
São Paulo: Editora Michalany, 277p.

Milton K 1979. Factors influencing leaf choice by howler monkeys: a test of some hypothesis of food selection by generalist herbivores. Am Naturalist 114: 362-367.

Montanari T, Bevilacqua E 2002. Effects of Maytenus ilicifolia Mart. On pregnant mice. Contraception 65: 171-175.

OECD 2007. Draft OECD guideline for the testing of chemicals. The Uterotrophic Bioassay in Rodents: short-term screening test for oestrogenic properties. OECD, Paris.

Peterson MC 1995. Progestogens, progesterone antagonists, progesterone, and androgens: synthesis, classification, and uses. Clinic Obs Gynecol 38: 813-820.

Ravichandran V, Suresh B, Sathishkumar MN, Elango K, Srinivason R 2007. Antifertility activity of hydroalcoholic extract of Ailanthus excelsa (Roxb): An ethnomedicine used by triblas of Nilgiris region in Tamilnadu. $J$ Ethnopharmacol 112: 189-191.

Rodriguez E, Aregullin M, Nishida T, Uehara S, Wrangham RW, Abromowski Z, Finlayson A, Towers GHN 1985. Thiarubrine-A, a bioactive constituent of Aspilia (Asteraceae) consumed by wild chimpanzees. Experientia 41: 419-420.

Salah AM, Gathumbi J, Vierling W, Wagner H 2002. Estrogenic and cholinergic properties of the methanol extract of Ruellia praetermissa Sceinf. Ex. Lindau (Acanthaceae) in female rats. Phytomedicine 9: 52-55.

Silva Jr EC 1981. A preliminary survey of brown howler monkeys (Alouatta fusca) at the cantareira reserve (São Paulo, Brazil). Rev Bras Biol 41: 897-909.

Shukla S, Mathur R, Prakash AO 1989. Histoarchitecture of the genital tract of ovariectomized rats treated with an aqueous extract of Moringa oleifera roots. J Ethnopharmacol 25: 249-261.

Sokal RR, Rohlf FJ. 1996. Biometry. The principles and practice of statistics in biological research. $3^{\text {rd }} \mathrm{ed}$. WH Freeman and Co., New York, p.850.

Stryer K. 1995. Food and medicinal plant selection by Muriquis, Brachyteles arachnoids. Abstracts of the workshop: Collaborative Drug Discovery: New transdisciplinary Approaches, Rio de Janeiro, 8-10 February.

Tewari RK, Pathak S, Prakash AO 1989. Biochemical and histological studies of reproductive organs in cyclic and ovariectomized rats supporting a non-hormonal action for neem oil. J Ethnopharmacol 25: 281-293.

Ulubelen A, Ertugrul L, Birman H, Yigit R, Erseven G, Olgac V 1994. Antifertility effects of some coumarins isolated from Ruta chalepensis and $R$. chalepensis var. latifolia in rodents. Phytother Res 8: 233-236.

Waynforth HB; Flecknell PA 1994. Ovariectomy (oophorectomy, spaying). In: Waynforth, HB; Flecknell, PA (Ed) Experimental and Surgical Technique. 2 ed. London: Academic Press, p. 276-278. 